\title{
Pengembangan Sistem Penagihan Biaya Kuliah Dengan Fitur WhatsApp Menggunakan Metode Scrum
}

\author{
Eko Setiadana $^{1}$, Septi Andryana ${ }^{2}$, Aris Gunaryati ${ }^{3}$ \\ ${ }^{1,2}$ Universitas Nasional, Jl. Sawo Manila No.61, Pejaten. Ps. Minggu. Jakarta 12520 \\ ${ }^{3}$ Teknik Informatika, Fakultas Teknologi Komunikasi dan Informasi, Jakarta \\ e-mail: ${ }^{1}$ ekosetiadana10@gmail.com, ${ }^{2}$ septi.andryana@civitas.unas.ac.id, \\ arisgunaryati@civitas.unas.ac.id
}

\begin{abstract}
Abstrak
Perkembangan teknologi informasi saat ini memungkinkan berbagai aplikasi untuk saling berkomunikasi. Salah satu teknologi yang muncul adalah layanan web. Layanan web menyelesaikan sebagai sistem perangkat lunak yang mendukung komunikasi mesin-ke-mesin melalui jaringan. Fokus utama penelitian ini adalah mengembangkan sistem penagihan biaya kuliah dengan menggunakan metode scrum agar lebih simple proses penagihan biaya kuliah, maka dikembangkan sebuah sistem yang dibangun berbasis website dengan fitur Whats App untuk mengirimkan notifikasi berupa pesan tagihan biaya kuliah kepada mahasiswa/mahasiswi. Pembuatan aplikasi ini didukung oleh beberapa teknologi seperti Sublime Text , MySQL dan WhatsApp
\end{abstract}

Kata kunci-Penagihan Biaya Kuliah, Metode Scrum, WhatsApp, Sublime Text dan MySQL

\begin{abstract}
The development of information technology today allows various applications to communicate with each other. One of the emerging technologies is web services. Web services resolve as software systems that support machine-to-machine communication over a network. The main focus of this research is to develop a tuition fee billing system using the Scrum method to make the tuition billing process simpler, so a website-based system is developed with the Whats App feature to send notifications in the form of tuition bill messages to students. Making this application is supported by several technologies such as Sublime Text, MySQL and WhatsApp
\end{abstract}

Keywords-Billing for Tuition Fees, Scrum Method, Whatsapp, PHP and MySQL

\section{PENDAHULUAN}

aat ini perguruan tinggi diberbagai daerah masih memiliki tata cara manual mengenai proses $N_{\text {pembayaran biaya kuliah dan belum ada sistemnya informasi berbasis teknologi untuk }}$ mengolah data administrasi biaya kuliah. Selain itu banyak mahasiswa/mahasiswi yang terlambat membayar biaya kuliah dengan berbagai alasannya.

Seiring permasalahan ini pihak kuliah harus segera melakukan transformasi dari pengelolaan secara manual menjadi digitalisas i[4]. Sistem yang dimaksud disini merupakan bagian dari sistem manusia [6]. Pada penitian ini, pengembangan sistem dilakukan menggunakan metode Scrum. Metode Scrum digunakan karena bersifat fleksibel dan dinamis, tidak seperti metode waterfall yang bersifat statis dan metode simulasi prototype [2]. Metode ini 
dinilai dapat meningkatkan proses dari tahap penyelesaian dan meningkatkan kualitas produk [3].

Scrum adalah metode pengelolaan perangkat lunak yang responsive serta berbasis metode agile yang mampu memberikan value dan manfaat yang terbaik terhadap suatu perangkat lunak yang akan dikembangkan [1]. Penulis menggunakan metode scrum yang memiliki sifat mudah dan cepat dalam mengembangkan sebuah sistem tagihan dengan dukungan fitur whatsapp dapat memecahkan masalah pada tagihan pembayaran yang dialami oleh bagian keuangan. Pengembangan sistem dalam penelitian ini didasarkan pada prinsip pengembangan perangkat lunak Aglie Software Development dengan metode Scrum [10].

\section{METODE PENELITIAN}

\subsection{Tahapan Penelitian}

Metode penelitian pembuatan sistem tagihan biaya kuliah berbasis web menggunakan metode notifikasi whatsapp. Langkah-langkah yang akan dilakukan yaitu :

1. Tahapan Pengumpulan Data

Pada tahap ini , penelitian didasarkan pada observasi dan tinjauan kepustakaan, yaitu :

a. Observasi

Pada tahap observasi dilakukan peninjauan mendalam tentang identifikasi kebutuhan terhadap aplikasi tagihan biaya kuliah yang ada dilapangan [3].

b. Tinjauan Pustaka

Pada penelitian kepustakaan dilakukan dengan cara mencari jurnal, buku, internet untuk bahan-bahan yang membantu mendefinisikan masalah

2. Analisa Sistem Berjalan

Pada tahap ini dengan mempertimbangkan berbagai permasalah sistem yang ada, hasil pengumpulan data diteliti dan dievaluasi, kemudian hasil pengumpulan data dan analisis tersebut dipakai peneliti untuk menentukan keperluan sistem yang dikembangkan.

3. Tahapan Pembangunan Sistem

Tahap pembangunan sistem yang digunakan adalah metode scrum. Tahapan ini meliputi membentuk tim scrum, membuat product backlog, dan beberapa tahapan sprint yaitu sprint planning, sprint backlog, daily scrum, sprint review, dan sprint restropective.

\section{2 Metode Scrum}

Scrum dikembangkan oleh Jeff Sutherland pada tahun 1993 untuk menciptakan metode pengembangan yang mengikuti prinsip-prinsip metode Aglie [5]. Scrum merupakan satu metode agile paling popular. Metode ini merupakan metode adaptif, cepat, fleksibel, dan efektif serta dapat memberikan hasil yang signifikan dengan cepat[7]. Scrum adalah sebuah kerangka kerja untuk pengembangan tambahan yang menggunakan satu atau lebih tim cross fungsional. Scrum menggunakan iterasi tetap yang disebut sprint, yang berlangsung selama satu hingga empat minggu. Tim scrum berusaha untuk menghasilkan peningkatan yang telah diuji disetiap iterasi. 


\section{HASIL DAN PEMBAHASAN}

\subsection{Penerapan Metode Scrum}

Saat merancang sistem penagihan biaya kuliah ini, langkah pertama adalah menyiapkan blacklog produk berdasarkan pengamatan dan persyaratan pengumpulan data.

Tabel 1. Product Backlog Sistem Tagihan Biaya Kuliah

\begin{tabular}{|c|l|}
\hline ID & \multicolumn{1}{|c|}{ Backlog Item Sistem Tagihan Biaya Kuliah } \\
\hline 1 & Mengambil data dari database \\
\hline 2 & Memeriksa adanya tagihan \\
\hline 3 & Menyimpan data ke dalam database \\
\hline 4 & Membuat tagihan berbentuk tertulis \\
\hline 5 & Mengambil data nomer whatsapp mahasiswa dari database \\
\hline 6 & Memunculkan tagihan ke message whatsapp \\
\hline 7 & Mengirimkan pesan whatsapp \\
\hline
\end{tabular}

Selanjutnya Sprint backlog yaitu membuat daftar yang dipilih dalam product backlog dan mengurutkan sesuai dengan prioritasnya sehingga dapat memproses sprint melalui desain dan mengevaluasi fungsinya untuk menghasilkan produk yang diinginkan.

Tabel 2. Sprint Backlog Sistem Tagihan Kuliah

\begin{tabular}{|c|l|c|}
\hline \multicolumn{2}{|c|}{ Sprint Backlog Sistem Tagihan Kuliah } \\
\hline ID & \multicolumn{1}{|c|}{ Story } & Priority \\
\hline 2 & Sistem memeriksa adanya tagihan & 1 \\
\hline 1 & Sistem mengambil data dari database & 2 \\
\hline 3 & Sistem menyimpan data ke dalam database & 3 \\
\hline 6 & Sistem memunculkan tagihan ke message whatsapp & 4 \\
\hline 4 & Sistem membuat tagihan berbentuk tertulis & 5 \\
\hline 5 & Sistem mengambil data nomer whatsapp mahasiswa dari database & 6 \\
\hline 7 & Sistem mengirimkan pesan whatsapp & 7 \\
\hline
\end{tabular}

Untuk kerangka kerja ini, penulis menggunakan pengembangan perangkat lunak yang fleksibel berdasarkan metodologi Scrum. Gambar 1 menunjukan kerangka kerja penelitian dengan metode Scrum [6]. 


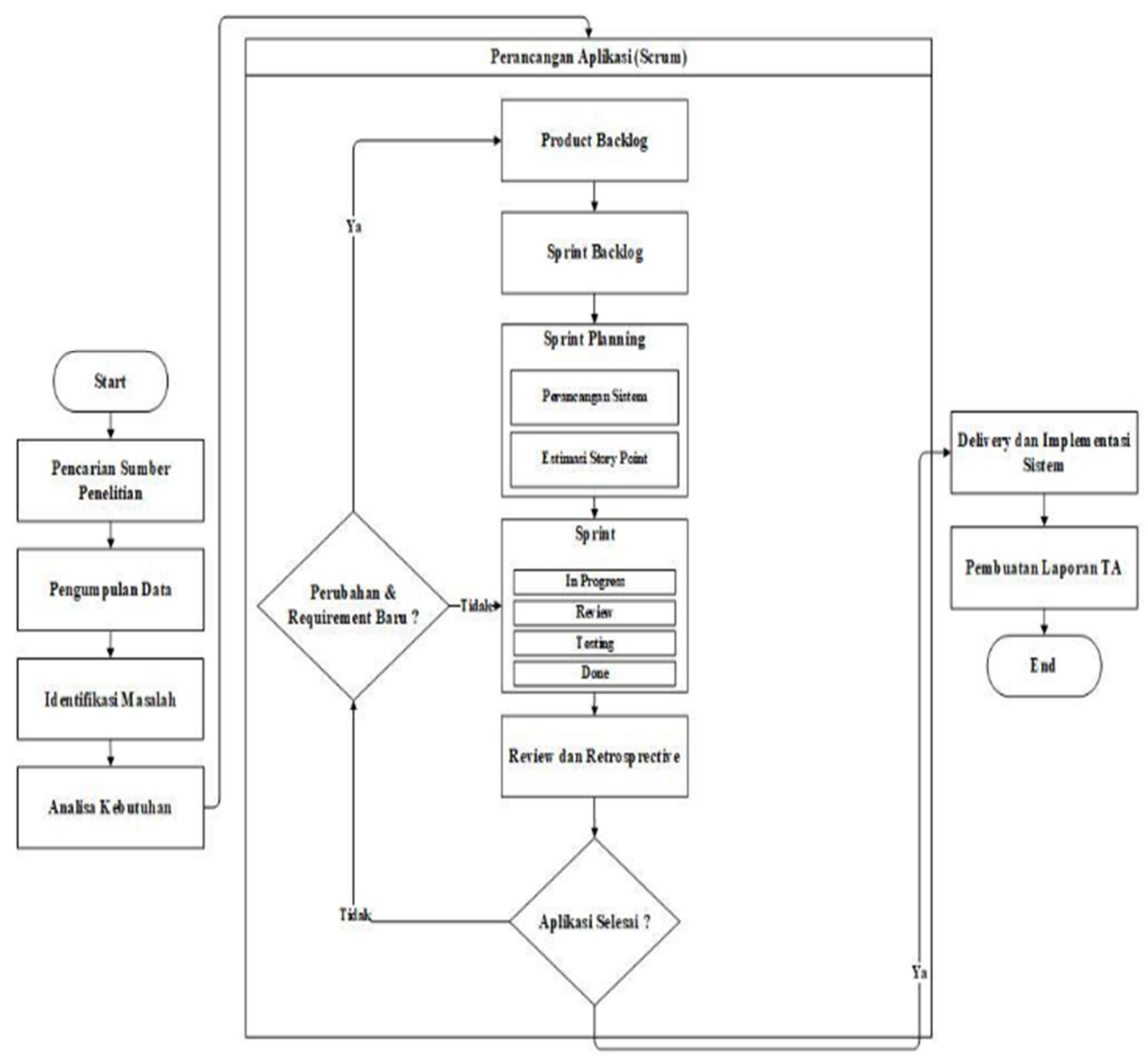

Gambar 1. Kerangka kerja pada metode scrum

Berikut ini penjelasan dari kerangka tersebut:

1. Mencari Sumber Penelitian

Proses penyusun dan penyampaian informasi tagihan kepada mahasiwa/mahasiswi menjadi bahan penelitian bagi penulis.

2. Pengumpulan Data

Data yang bisa dikumpulkan diantaranya nomer whatsapp mahasiswa/mahasiswi, data rincian pembayaran, dan data isi pesan yang akan di tercantum dalam pesan Whatsapp yang dikirim.

3. Identifikasi Masalah

Mengidentifikasi masalah merupakan memproses dalam pembuatan dan tidak adanya pengingatan tagihan waktu adanya pembayaran spp.

4. Analisasi Kebutuhan

Analisa kebutuhan merupakan kebutuhan dari sistem yang dikembangkan. Beberapa yang diperlukan antaralain mendata nomer whatsapp, membuat isi whatsapp berupa pesan tagihan, dan mengirimkan pesan berupa tagihan ke nomer whatsapp mahasiswa/mahasiswi.

5. Pengembangan Apliaksi

Proses pengembangan aplikasi ini terdiri dari beberapa tahapan yang berbeda. 
a. Product Backlog

Tahapan ini berisi Product blacklog dibentuk berdasarkan requitment yang dihasilkan dari observasi dan tinjauan pustaka. Dalam product backlog yang bersifat dinamis sehingga, product backlog akan terus bertambah apabila mendapatkan umpan balik dari pengguna selama proses peninjauan.

b. Sprints Backlog

Merupakan product backlog yang dibagi menjadi beberapa bagian untuk diproses dengan sprint. Biasanya sprint membutuhkan waktu 1 sampai 4 minggu sesuai kesepakatan dengan tim scrum.

c. Sprint Planning

Perencanaan sprint yaitu merencanakan pada backlog produk sprint. Dalam tahapan ini meliputi perancangan sistem, pembuatan database, pembuatan desain sistem yang akan dibuat, dan alur proses sistem tagihan biaya kuliah.

d. Sprint

Sprint berisikan bagian kerja yang diperlukan untuk memenuhi keperluan yang diidentifikasi oleh backlog, dan backlog wajib selesai dalam waktu yang telah ditentukan. Pada sprint, mulailah membuat aplikasi tagihan biaya kuliah berdasarkan sprint planning. Tahapan sprint meliputi perkembangan, tinjauan pustaka, pengujian dan penyelesaian.

e. Review dan Retrosprective

Setelah fase sprint selesai, akan dilakukan pemeriksaan akhir terhadap sistem tagihan, pemeriksaan sistem tagihan ini untuk mencari kesalahan pada sistem. Jika adanya kesalahan dalam sistem, team akan memperbaiki, jika terdapat perubahan, maka akan ditambahkan ke blacklog tambahan disprint berikutnya. Jika tidak ditemukan kesalahan sistem siap untuk dirilis.

6. Implementasi Sistem

Berikutnya merupakan implementasi sistem, yaitu merilis aplikasi tagihan untuk siap digunakan.

7. Pembuatan Laporan

Langkah akhir yaitu membuat laporan analisa setelah menerima hasil penelitian, yang berisi informasi tentang penelitian dan hasil yang diperoleh selama penelitian.

\subsection{Use Case Diagram}

Pada use case diagram ini, admin dan tata usaha terbagi menjadi 6 akses, akses login /registrasi, akses melihat dan mengatur data siswa, akses mengatur data kelas, akses mengatur pembayaran, akses mengirimkan pesan whatsapp, serta akses logout. Sedangkan user hanya menjadi 3 akses, akses login, akses menerima whasapp, serta akses logout. Gambar dari akses akses tersebut dapat dilihat pada use case berikut ini. 


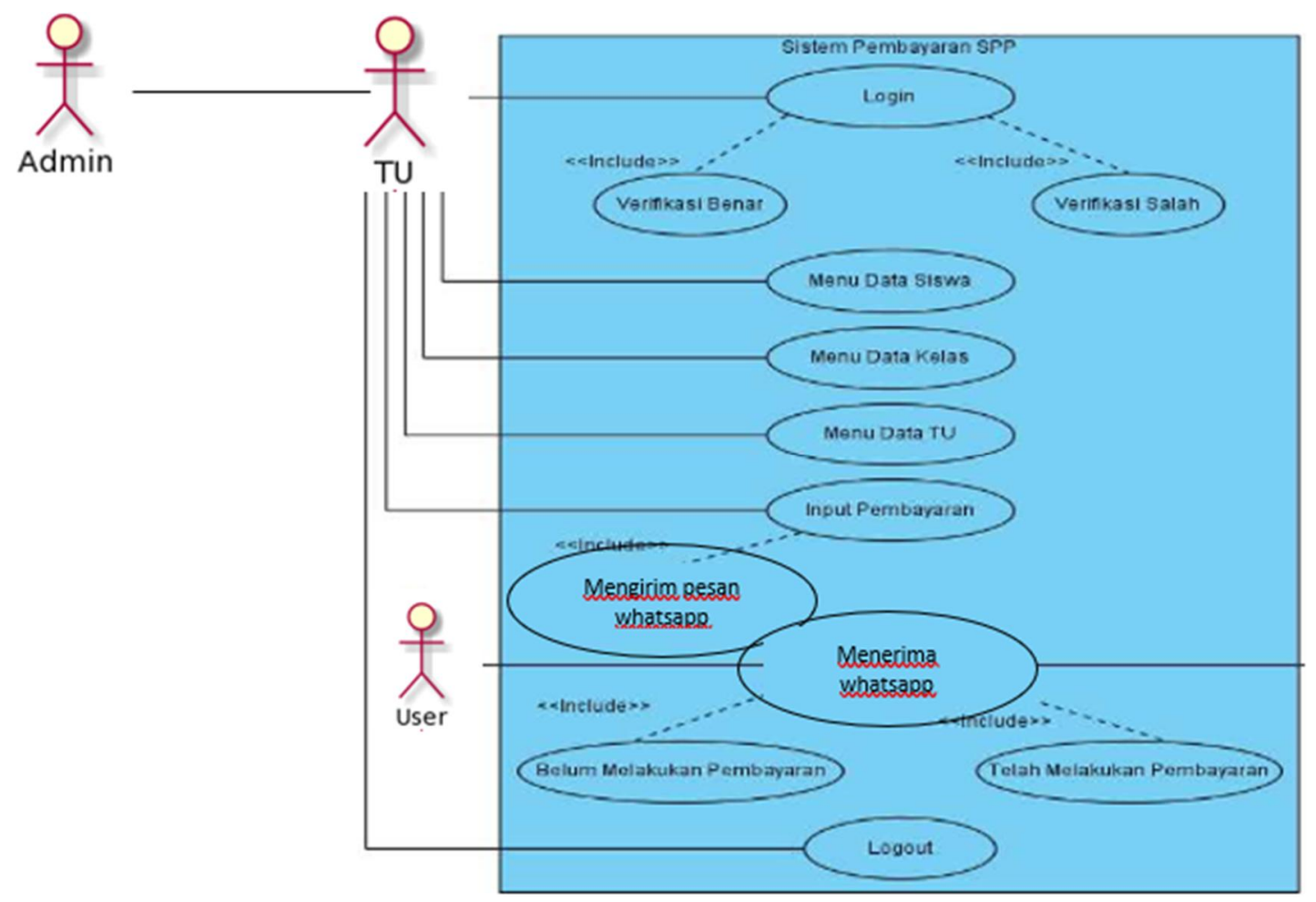

Gambar 2. Use Case Sistem Tagihan Biaya Kuliah

\subsection{Implementasi Program}

1. Halaman Login

Fitur ini berada pada laman paling awal website. Admin, TU dan Mahasiswa untuk masuk kedalam website tagihan kuliah. Tampilan dapat dilihat pada Gambar 3.

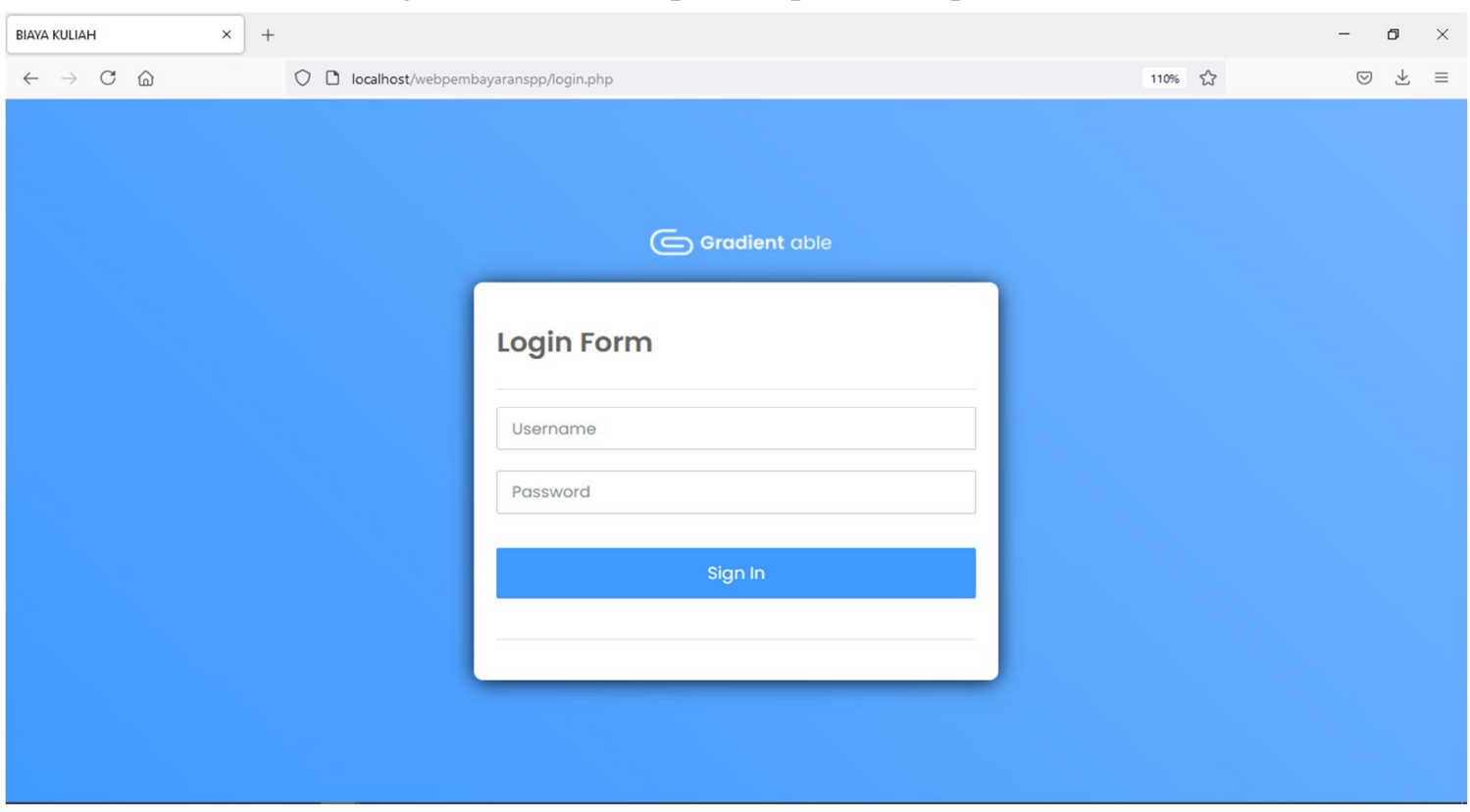

Gambar 3. Tampilan From Login 


\section{Halaman Prodi}

Pada halaman prodi, admin dan TU sama dapat membuat nama prodi, fakultas dan keterangan prodi tersebut.

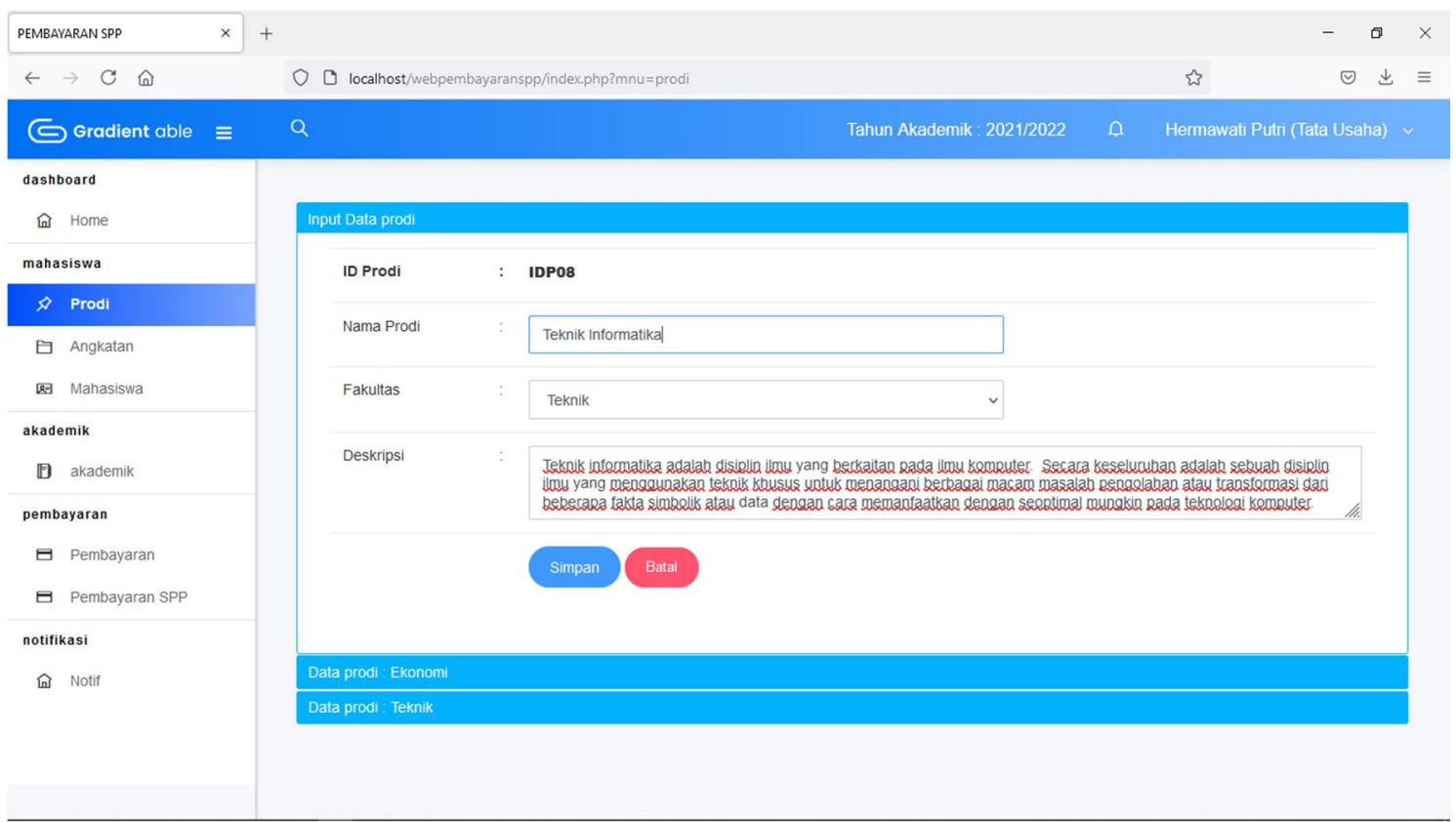

\section{Gambar 4. Tampilan Halaman Prodi}

3. Halaman Angkatan

Pada halaman Angkatan ini, admin dan TU bisa membuat tahun angkatan pada perkuliahan, uang gedung perkuliahan dan SPP yang dibutuhkan pada perkuliahan.

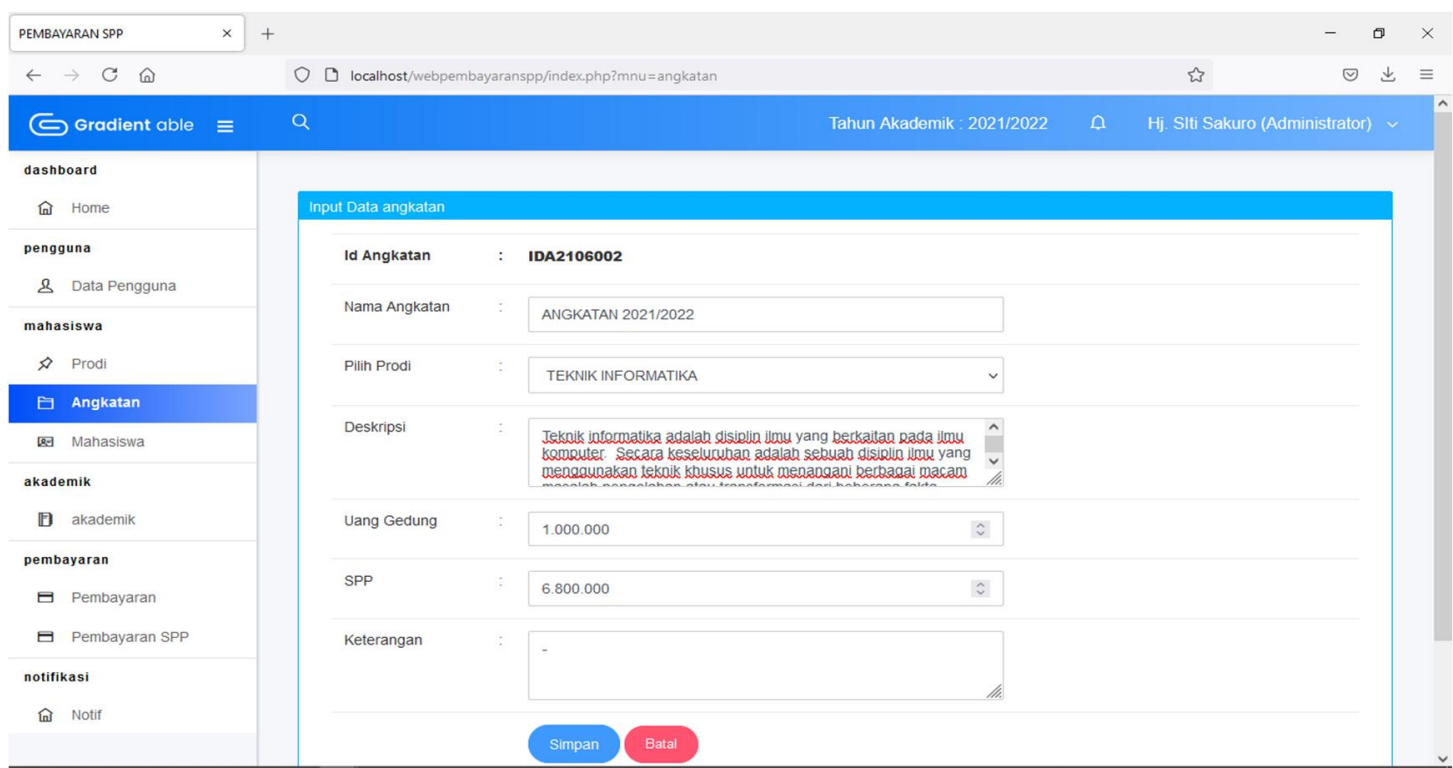

Gambar 5. Tampilan Halaman Angkatan 
4. Halaman Mahasiswa

Pada halaman ini, admin dan TU dapat membuat daftar akun mahasiswa dengan mengisi form mahasiswa.

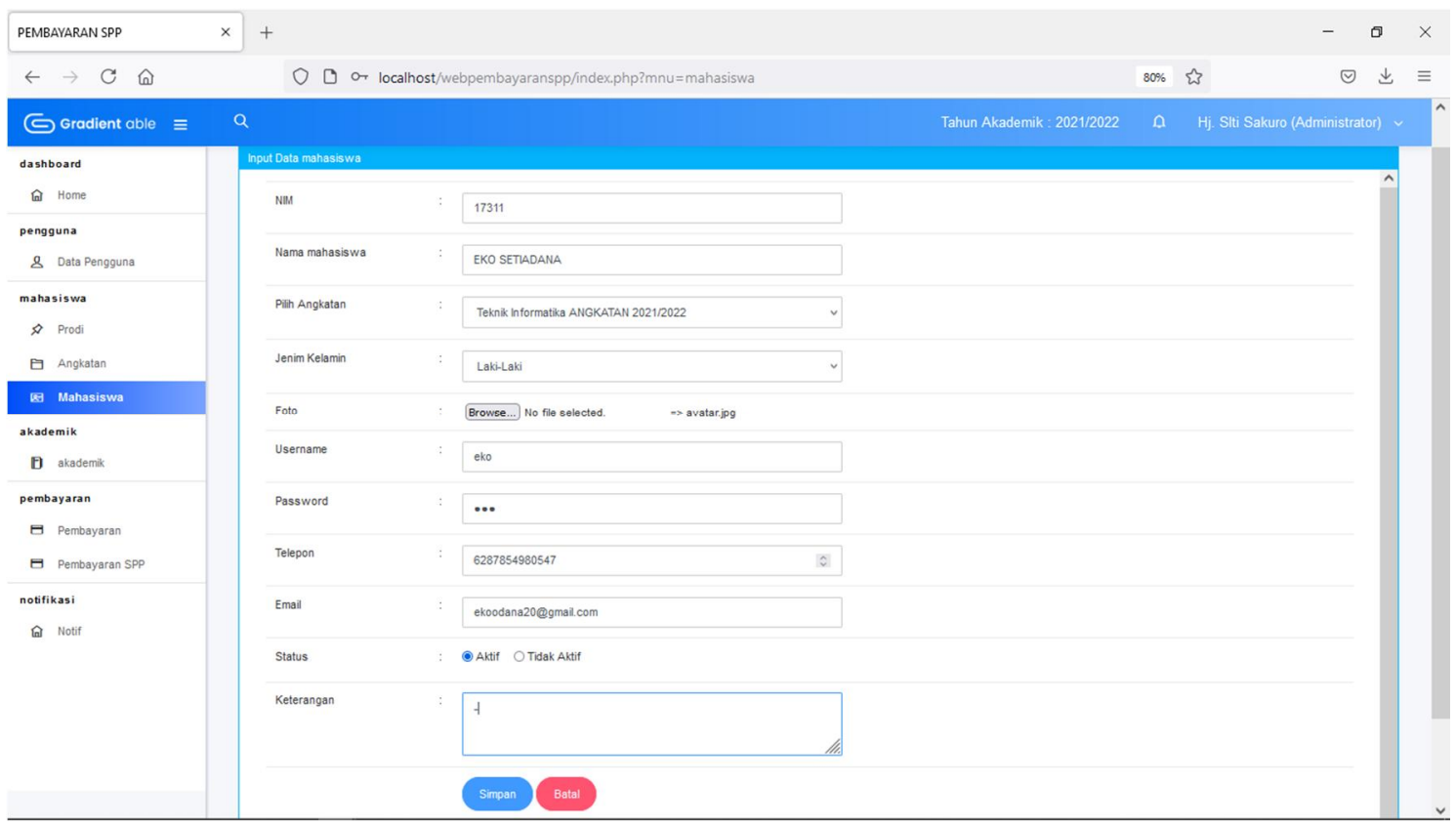

Gambar 6. Tampilan Halaman Mahasiswa

5. Halaman Notifikasi

Pada halaman ini admin dan TU memberikan notifikasi kepada mahasiswa melalu nomer whatsapp.

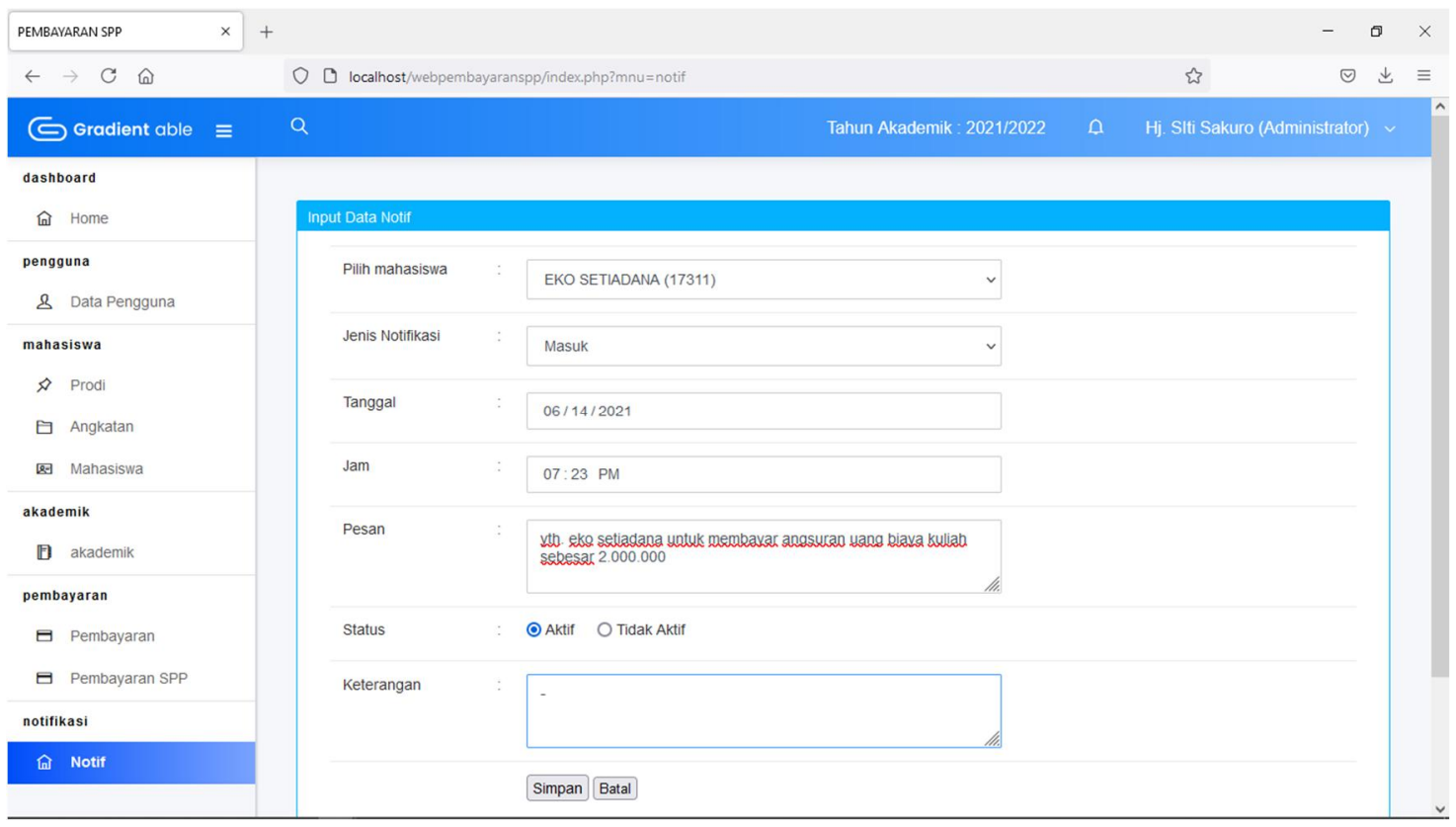

Gambar 7. Tampilan Halaman Notifikasi 
6. Halaman Pembayaran pada Mahasiswa mandiri

Pada halaman ini, mahasiswa dapat mengupload/menginput bukti pembayaran secara

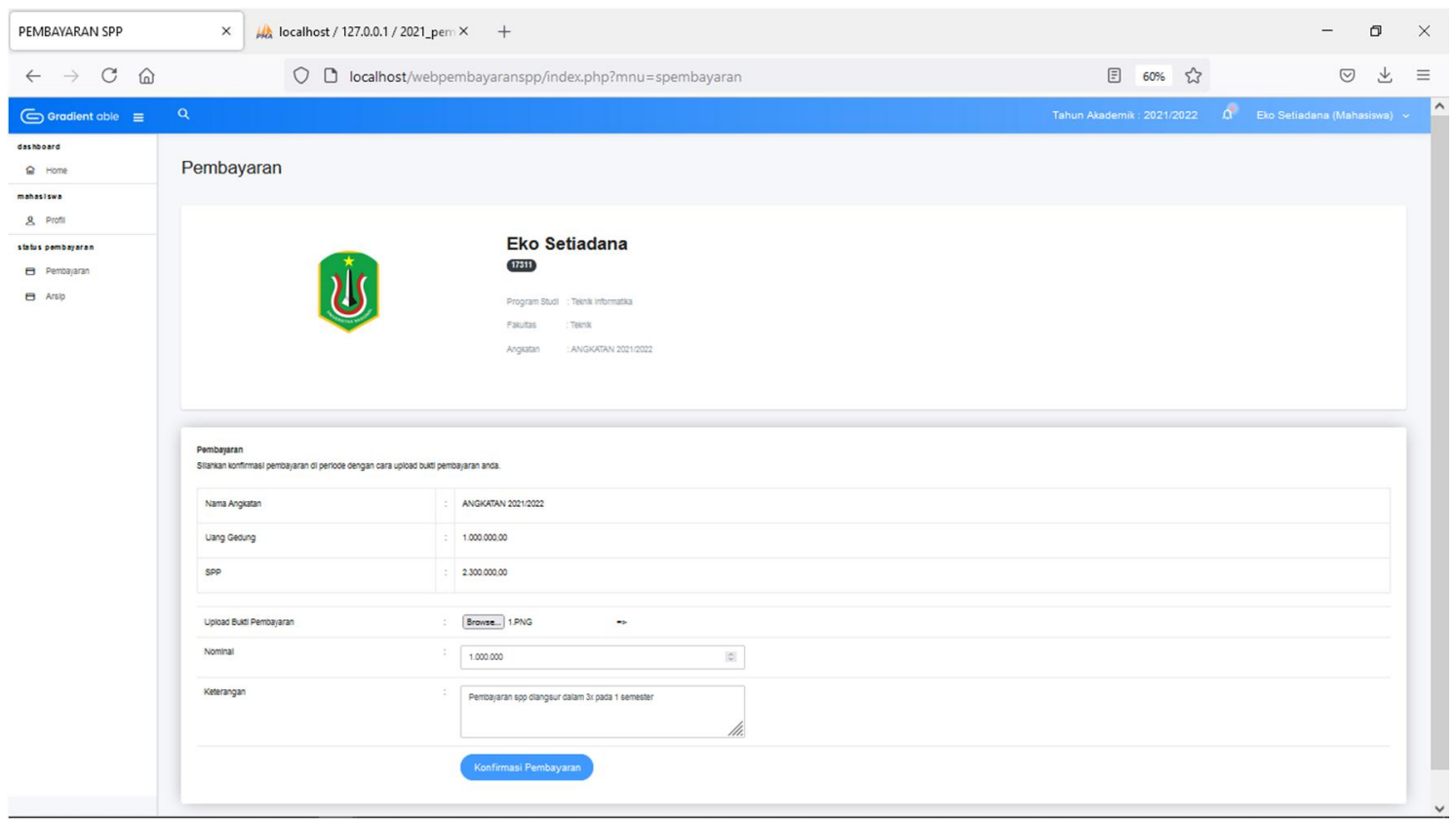

Gambar 8. Tampilan Bukti Pembayaran pada Mahasiswa

7. Halaman Arsip pada Mahasiswa

Pada halama arsip ini, mahasiswa dapat melihat histori keuangan yang telah dibayarkan.

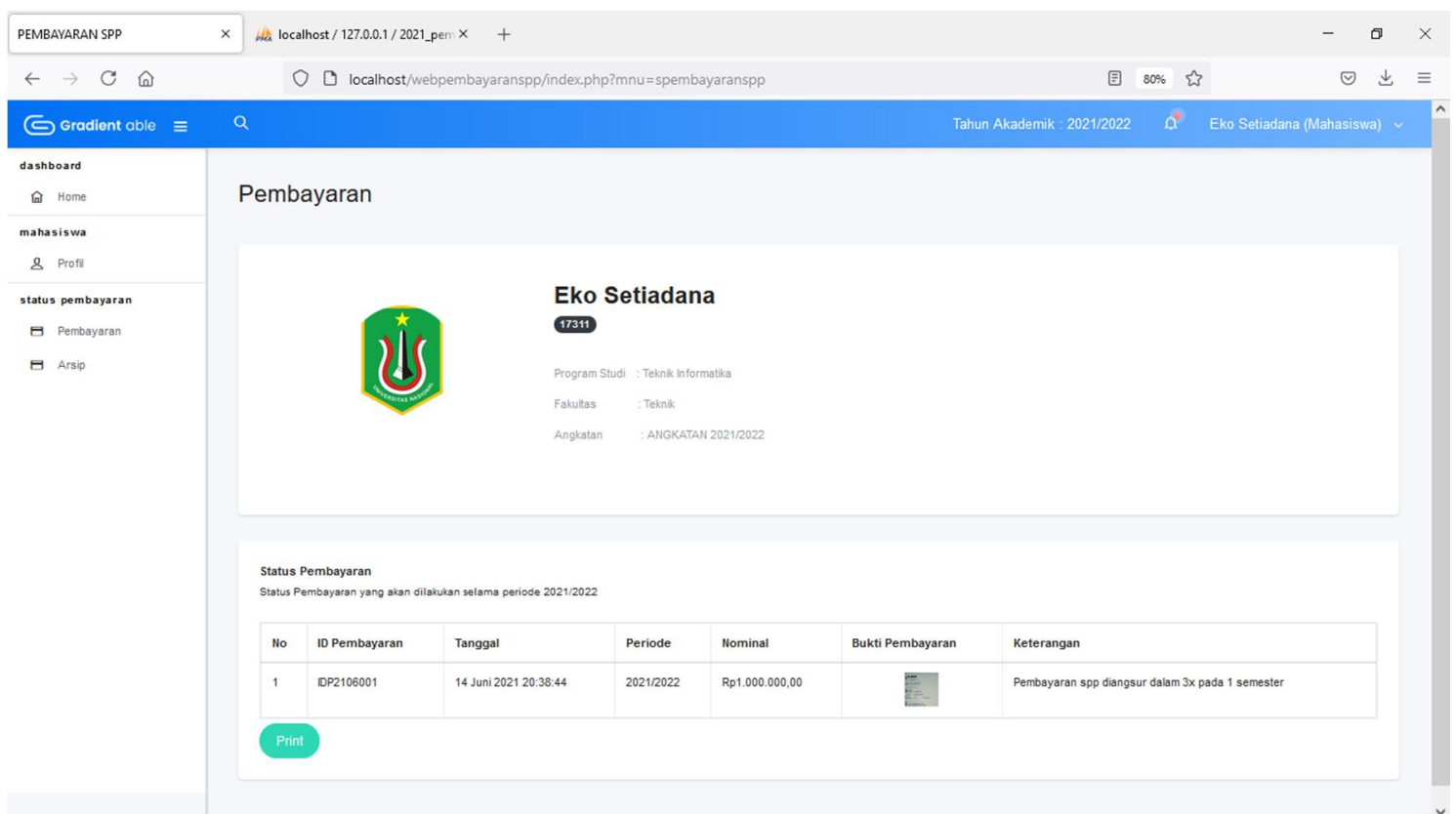

Gambar 9. Tampilan History Bukti Pembayaran 


\section{Halaman Hasil}

Pada halaman ini mahasiswa mendapatkan pesan dari pihak keuangan kampus melalau whatsapp untuk melunasi angsuran spp.

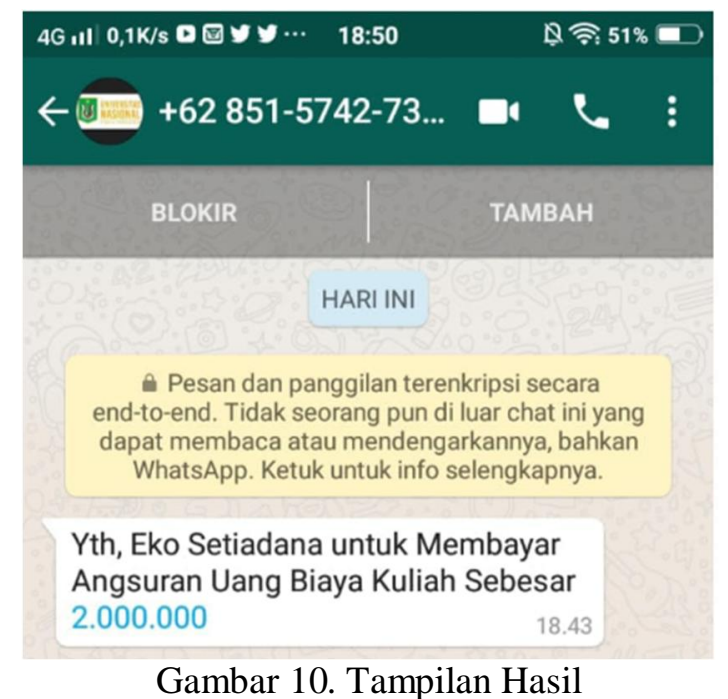

\subsection{Pengujian Sistem}

Tabel 3. Pengujian Sistem

\begin{tabular}{|c|c|c|c|c|c|c|}
\hline $\begin{array}{l}\mathbf{N} \\
\mathbf{0}\end{array}$ & $\begin{array}{c}\text { Skenario } \\
\text { Pengujian }\end{array}$ & & Test Case & $\begin{array}{l}\text { Hasil yang di } \\
\text { harapkan }\end{array}$ & $\begin{array}{c}\text { Hasil } \\
\text { Pengujian }\end{array}$ & $\begin{array}{c}\text { Kesim } \\
\text { pulan }\end{array}$ \\
\hline 1 & $\begin{array}{l}\text { Menampilkan } \\
\text { halaman } \\
\text { landing }\end{array}$ & 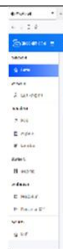 & 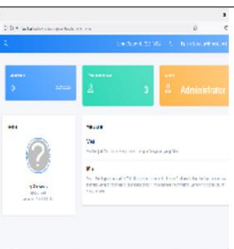 & $\begin{array}{l}\text { Sistem akan } \\
\text { menampilkan } \\
\text { informasi website }\end{array}$ & 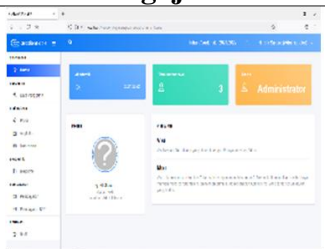 & Valid \\
\hline 2 & $\begin{array}{l}\text { User harus } \\
\text { Melakukan } \\
\text { Registrasi } \\
\text { melalui } \\
\text { Tata Usaha }\end{array}$ & 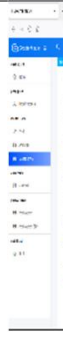 & 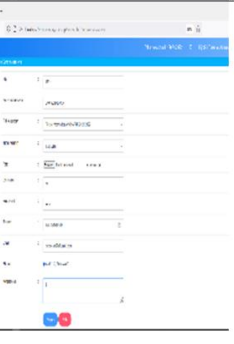 & $\begin{array}{l}\text { Tata Usaha } \\
\text { berhasil mengisi } \\
\text { data Registrasi } \\
\text { Mahasiswa } \\
\text { dengan benar dan } \\
\text { data akan masuk } \\
\text { pada tampilan } \\
\text { data mahasiswa } \\
\text { pada database }\end{array}$ & 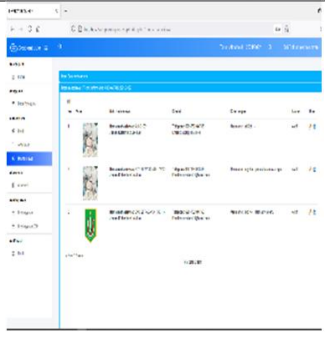 & Valid \\
\hline 3 & $\begin{array}{l}\text { Tata Usaha, } \\
\text { User Login } \\
\text { tidak mengisi } \\
\text { username } \\
\text { maupun } \\
\text { password }\end{array}$ & $\cdots$ & 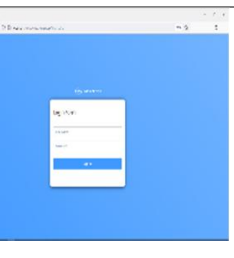 & $\begin{array}{l}\text { Sistem akan menolak } \\
\text { akses login dan } \\
\text { menampilkan pesan } \\
\text { "Otentikasi Login } \\
\text { GAGAL !,Silakan } \\
\text { cek data Anda } \\
\text { kembali..." }\end{array}$ & tos & Valid \\
\hline
\end{tabular}




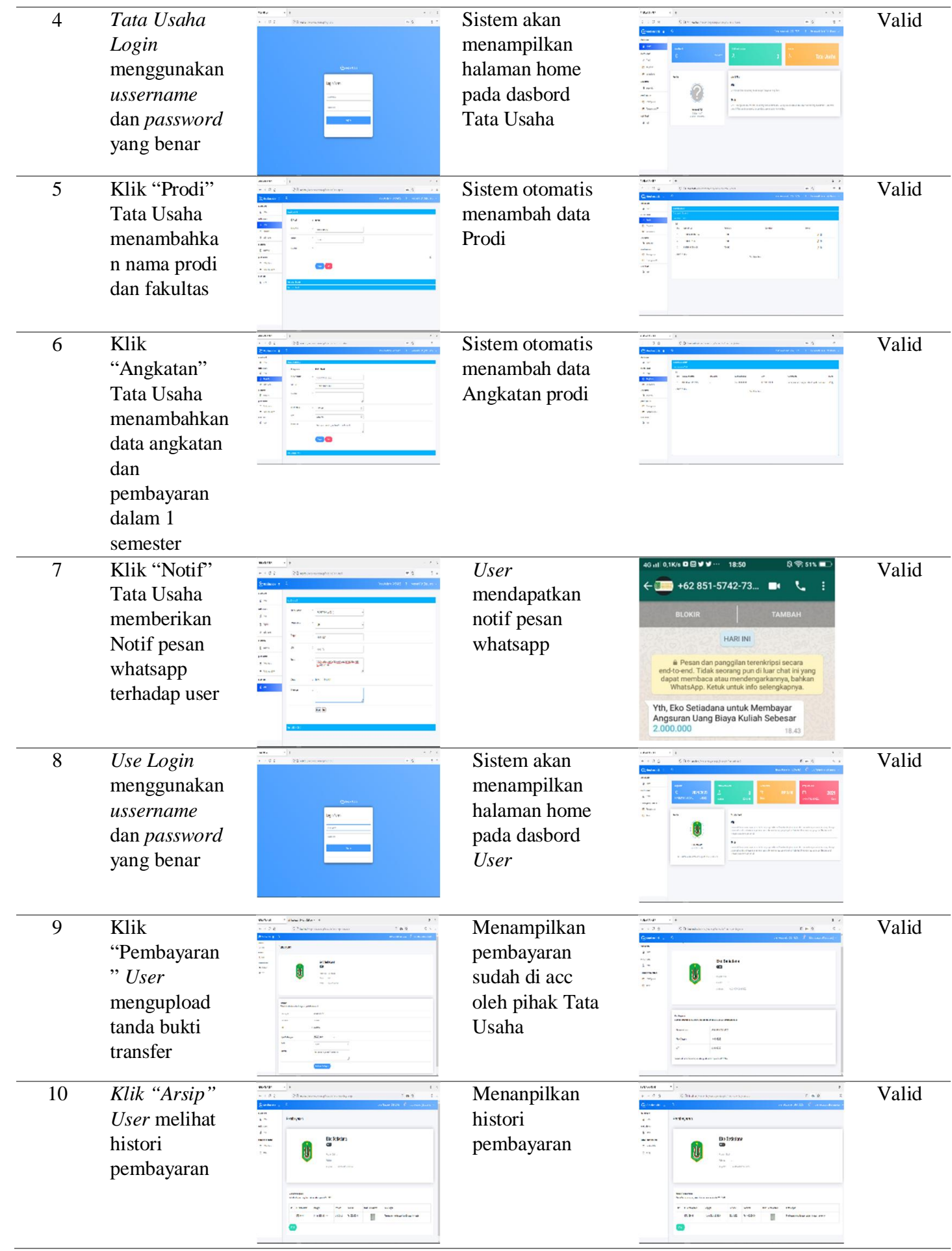

\section{KESIMPULAN}

Hasil dari penelitian mengenai tagihan kuliah menggunakan metode scrum, dapat disimpulkan bahwa pengembangan Sistem Penagihan Biaya Kuliah dibagi menjadi beberapa tahap pengembangan, yaitu : Product Backlog, Sprint Backlog, Sprint Planning, Sprint, 
kemudian Review dan Restroprective. Pemilihan metode pengembangan scrum lebih tepat karena bersifat dinamis dan fleksibel dibandingkan dengan metode waterfall yang memakan waktu cenderung lama dan membutuhkan banyak biaya. Fungsi utama dari Sistem Penagihan Biaya Kuliah adalah membuat tagihan secara elektronik, melampirkan invoice pada pesan dan mengirimkan invoice whatsapp kepada mahasiswa. Tagihan Biaya Kuliah memudahkan petugas keuangan dalam membuat dan mengirimkan tagihan kepada mahasiswa/mahasiswi.

\section{SARAN}

Saran untuk penelitian lanjutan yaitu untuk dapat lebih meningkatkan dalam segi kualitas, menambahkan beberapa fungsi seperti file lampiran dalam bentu file pdf serta perbarui beberapa dari segi desain agar lebih terlihat lebih menarik. Mungkin juga sistem dikembangkan dalam konteks latar belakang masalah untuk menghasilkan lebih banyak materi yang berbeda dimasa depan.

\section{DAFTAR PUSTAKA}

[1] Suharno, H. R., Gunantara, N., \& Sudarma, M. Analisis Penerapan Metode Scrum pada Sistem Informasi Manajemen Proyek Dalam Industri \& Organisasi Digital, Majalah Ilmiah Teknologi Elektro, 19(2), 203-210.

[2] Hadji, S., Taufik, M., \& Mulyono, S. 2020, Implemetasi Metode Scrum pada Pengembangan Aplikasi Delivery Order Berbasis Website (Studi Kasus pada Rumah makan Lombok Idjo Semarang), Prosiding Konferensi Ilmiah Mahasiswa Unissula (KIMU) Klaster Engineering.

[3] Septianto, T. 2020, Pengembangan Aplikasi Traveling Social Media Dengan Scrum, Jurnal Teknika, 12(2), 75-79.

[4] Arsyawalfa, M. I., \& Handriyantini, E. 2020, Pengembangan Sistem Informasi Pemungutan Pajak Reklame Berbasis Website Mnggunakan Metode Scrum Pada Badan Pendapatan Daerah Kabupaten Lombok Barat, J-INTECH, 8(02), 53-64.

[5] Fernando, D., Anharudin, A., \& Fadli, F. 2018, Rancang Bangun Aplikasi E-Portofolio Hasil Karya Mahasiswa Unsera Menggunakan Metode Scrum, JSil (Junal Sistem Informasi), 5(1).

[6] Rosyani, P. (2020,March), Perancangan Sistem Informasi Penerimaan Siswa Baru Menggunakan Metode Scrum pada SMA Seruni Putih Pamulang, In PROSIDING SEMINAR INFORMATIKA DAN SISTEM INFORMASI (Vol. 3, No. 3, pp. 196-202).

[7] Hadinata, N., \& Nasir, M. 2017, Implementasi Metode Scrum Dalam Rancang Bangun Sistem Informasi Penjualan (Study Kasus: Penjualan Sperpart Kendaraan), Jurnal Ilmiah Betrik: Besemah Teknologi Informasi dan Komputer, 8(01), 22-27.

[8] Prabowo, W. A., \& Wiguna, C. 2021, Sistem Informasi UMKM Bengkel Berbasis Web Menggunakan Metode SCRUM, Jurnal Media Informatika Budidarma, 5(1), 149-156. 
[9] Prastio, C. E. 2018, Aplikasi Self-Service Menu Menggunakan Metode Scrum Berbasis Android, Petir: Jurnal Pengkajian dan Penerapan Teknik Informatika, 11(2), 203-220.

[10] Rizaldi, T., Setyohadi, D. P. S., \& Riskiawan, H. Y. 2016, Implementasi Metodologi SCRUM Dalam Pengembangan Sistem Pembayaran Elektronik pada Usaha Mikro Kecil Menegah. 